\title{
COMPLEXIMETRIC DETERMINATION OF CALCIUM IN PATHOLOGICAL AND PHYSIOLOGICAL SPECIMENS
}

\author{
BY \\ D. N. BARON AND JOYCE L. BELL \\ From the Department of Chemical Pathology, the Royal Free Hospital, London
}

(RECEIVED FOR PUBLICATION OCTOBER 21, 1958)

Titrimetric estimation of calcium with disodium ethylene diamine tetra-acetate (E.D.T.A., sodium edetate), as performed on serum (Baron and Bell, 1957), cannot be applied directly to most other biological specimens because of their high concentration of phosphate. A high ratio of phosphate to calcium in the material titrated causes a drawn. out and inaccurate endpoint. A rapid procedure for calcium determination has been devised which gives accurate results after separation of phosphate.

\section{METHOD \\ Reagents}

(1) Deionized or glass-distilled water must be used throughout all stages of the procedure.

(2) For Ashing. - $\mathrm{N}-\mathrm{HCl}$ is used.

(3) For Phosphate Separation (Horner, 1955).(a) $48 \%$ morpholine nitrate : $50 \% \mathrm{v} / \mathrm{v} \mathrm{HNO}_{3}$ is slowly added to $28 \mathrm{ml}$. morpholine at $0^{\circ} \mathrm{C}$. until the solution is neutral or slightly acidic to B.D.H. universal indicator paper (about $40 \mathrm{ml}$. acid is required). The solution is then diluted to $100 \mathrm{ml}$. with water.

(b) The morpholine nitrate-nitric acid reagent is a $1: 1$ mixture of $48 \%$ morpholine nitrate and $25 \%$ $\mathrm{v} / \mathrm{v} \mathrm{HNO}_{3}$.

(c) $66 \% \mathrm{w} / \mathrm{v}$ sodium tungstate $\mathrm{Na}_{2} \mathrm{WO}_{4} 2 \mathrm{H}_{2} \mathrm{O}$.

(4) For Titration.-The following reagents are made up :

(a) $40 \% \mathrm{w} / \mathrm{v} \mathrm{NaOH}$.

(b) Glycine buffer $p \mathrm{H} 12.66$ of $20 \mathrm{ml}$. of 0.1 $M$-glycine+ $0.1 M \mathrm{NaCl}$ and $80 \mathrm{ml}$. of $0.1 M \mathrm{NaOH}$.

(c) E.D.T.A. solution for which $0.93 \mathrm{~g}$. disodium ethylene diamine tetra-acetate (E.D.T.A.) is dissolved in water and the solution made up to $1,000 \mathrm{ml}$.

(d) Stock Calcium Solution (100 mg./100 ml.).-To $2.5 \mathrm{~g}$. $\mathrm{CaCO}_{3}$ A.R. (previously dried at $105^{\circ}$ for 24 hours) is added about $200 \mathrm{ml}$. water followed by $50 \mathrm{ml}$. N-HCl. After standing overnight the solution is diluted to $1,000 \mathrm{ml}$.

(e) Calcein-thymolphthalein Indicator. - Calcein, $0.2 \mathrm{~g}$. (the Hopkin and Williams material has been found suitable), $0.12 \mathrm{~g}$. thymolphthalein, and $20 \mathrm{~g}$. potassium chloride are ground together to a fine powder (Tucker, 1957). This mixture is stable for several months when kept dry.
Preparation of Sample for Phosphate Separation from Original Biological Specimen

Serum/Plasma and Similar Fluids. - No preparation or phosphate separation required, unless the serum is grossly icteric or haemolysed.

Faeces. - The specimen is mixed and diluted to a thin, creamy consistency, of expected calcium concentration $10-30 \mathrm{mg} . / 100 \mathrm{ml}$. It is usually convenient to homogenize the faeces (with addition of water if necessary), then an aliquot is taken which is equivalent to $1 / 10$ of the daily faecal excretion and this is diluted 1 in 5 .

Food.-The food is cut into small pieces and homogenized, adding water if necessary. The approximate calcium content of food is usually known, and it should be diluted so that the expected calcium concentration is about $20 \mathrm{mg} . / 100 \mathrm{ml}$.

Milk.-The specimen is diluted so that the expected calcium concentration is about $20 \mathrm{mg}$. $/ 100$ $\mathrm{ml}$. A dilution of 1 in 5 is normally suitable for cow's milk.

Urine (and Other Fluids).- The calcium concentration of urine varies over a wide range. Very often in clinical work an estimate of the urinary calcium concentration can be obtained by reference to the patient's condition. This is not usually possible in experimental work and then it is advisable to carry out a screening test as described below. The commonly used Sulkowitch test (Barney and Sulkowitch, 1937) for urinary calcium was not found reliable enough for our purposes.

To each of two test-tubes are added $5 \mathrm{ml}$. of glycine buffer, $1 \mathrm{ml}$. of E.D.T.A., and $0.5-1 \mathrm{mg}$. of calceinthymolphthalein indicator. Then $2 \mathrm{ml}$. urine is added to the first tube and $0.2 \mathrm{ml}$. to the second tube. The calcium concentration of the urine may then be estimated by viewing in diffuse light.

\begin{tabular}{|c|c|c|}
\hline Colour & $\begin{array}{c}\text { Calcium } \\
\text { Concentration }\end{array}$ & $\begin{array}{c}\text { Subsequent } \\
\text { Procedure }\end{array}$ \\
\hline Both tubes green & More than $50 \mathrm{mg} . /$ & The urine is diluted 1 in \\
\hline $\begin{array}{l}\text { First tube green, } \\
\text { second mauve } \\
\text { Both tubes mauve }\end{array}$ & $\begin{array}{l}10-50 \mathrm{mg} \cdot / 100 \mathrm{ml} . \\
\text { Less than } 10 \mathrm{mg} \cdot 100 \\
\text { ml. }\end{array}$ & $\begin{array}{l}\text { The urine is used neat } \\
\text { A larger volume of } \\
\text { phosphate-free super- } \\
\text { natant is used for } \\
\text { titration; } 3 \mathrm{ml} \text { is } \\
\text { usually suitable }\end{array}$ \\
\hline
\end{tabular}


No failure of recovery is encountered with urines containing calcium deposits of calcium phosphate or oxalate. The urine must be shaken thoroughly before an aliquot is taken for phosphate precipitation, at which stage these calcium salts go into solution.

Bone.-Marrow and fat-free bone is prepared by refluxing with Bloor's mixture as described by Follis (1952). About $100 \mathrm{mg}$. of the prepared bone is digested at $100^{\circ} \mathrm{C}$. in about $10 \mathrm{ml}$. of $3 \mathrm{~N}-\mathrm{HCl}$ for a few hours until solution is complete. The volume is then adjusted to $100 \mathrm{ml}$. with distilled water.

Teeth.-Whole tooth, enamel, or dentin is ground and about $60 \mathrm{mg}$. of the resulting powder is digested at $100^{\circ} \mathrm{C}$. in $10 \mathrm{ml}$. of $3 \mathrm{~N}-\mathrm{HCl}$, and the solution made up to $100 \mathrm{ml}$. with water.

Soft Tissues.-These usually have a calcium concentration less than $10 \mathrm{mg} . / 100 \mathrm{ml}$. Homogenization with dilution lowers the calcium concentration too much for accurate analysis. Homogenization without dilution is often difficult unless special disintegrators are available, and calcium extraction has not always been complete. Hence preparation by ashing is generally advised.

About $10 \mathrm{~g}$. fresh tissue is weighed. The water content can be estimated at this stage if required. The specimen is ashed overnight at about $500^{\circ} \mathrm{C}$. After cooling, the ash is dissolved in a small amount of $\mathrm{N}-\mathrm{HCl}$ (about $1 \mathrm{ml}$. is usually required) and the solution made up to $5 \mathrm{ml}$. with water.

\section{Phosphate Separation from Prepared Sample}

In a stoppered tube are mixed $2 \mathrm{ml}$. of the prepared sample made as above, $1 \mathrm{ml}$. tungstate reagent, and $2 \mathrm{ml}$. morpholine nitrate-nitric acid reagent. This precipitates phosphate and protein. The mixture is allowed to stand for one hour at room temperature then centrifuged. The supernatant is used for titration.

\section{Titration}

Test.-Supernatant $(1 \mathrm{ml}$.) is pipetted into a small white crucible and a few drops of $40 \% \mathrm{NaOH}$ added until the mixture is strongly alkaline ( $p \mathrm{H}$ about 12 ). When setting up the method it is necessary to find the correct amount of alkali by taking a separate aliquot of the supernatant and bringing it up to $\mathrm{pH} 12$ using B.D.H. 1014 indicator. With practice, this is unnecessary since the shade of the calceinthymolphthalein indicator enables the correct $p \mathrm{H}$ to be gauged. In the latter case, calcein-thymolphthalein is added to the $1 \mathrm{ml}$. supernatant before adding alkali. Glycine buffer $(5 \mathrm{ml}$.) is then added.

Blank.-This is made up of $1 \mathrm{ml}$. distilled water and $5 \mathrm{ml}$. glycine buffer. The blank titration is negligible when the water used is very pure.

Standard.-The standard consists of $1 \mathrm{ml}$. standard calcium solution $(10 \mathrm{mg} . / 100 \mathrm{ml}$.) and $5 \mathrm{ml}$. of glycine buffer.

A small knife point $(0.5-1 \mathrm{mg}$.) of indicator is added to each solution and they are titrated with E.D.T.A. until they change colour from green to mauve which is stable for at least five seconds. At this stage adding further E.D.T.A. gives no further change of colour.

It is convenient to use a small magnetic stirrer for these titrations. If a stirrer is not available the mixture should be continually agitated during titration. This procedure is adapted from that previously described for serum calcium (Baron and Bell, 1957). The only modifications that have been made to the original titration procedure are the use of the magnetic stirrer and of opaque white dishes as the titration vessels. Daylight or a daylight bulb should be used.

Procedure for Serum.-Serum $(1 \mathrm{ml}$.) is titrated directly in $5 \mathrm{ml}$. of glycine buffer; the colour change is orange-green to pink. Alternatively a blank titration can be carried out on $5 \mathrm{ml}$. of buffer solution, $1 \mathrm{ml}$. of serum added, and the titration completed: this gives the green-to-mauve end-point. Jaundice makes the end-point difficult to read but is overcome by preliminary phosphate-protein precipitation. If there is gross haemolysis, phosphate - protein precipitation should be performed, and 2 drops of $1 \% \mathrm{NaCN}$ added to the supernatant before titration to complex the iron.

\section{Calculation}

$\frac{\text { Test }- \text { Blank }}{\text { Standard-Blank }} \times 10=\mathrm{mg}$. calcium $/ 100 \mathrm{ml}$. of supernatant (or untreated serum).

Phosphate precipitation involves a dilution of 2 in 5 , therefore,

$\begin{gathered}\text { mg. calcium } / 100 \mathrm{ml} . \\ \text { of prepared sample }\end{gathered}=\frac{\text { Test }- \text { Blank }}{\text { Standard-Blank }} \times 25$.

A further calculation may be necessary to convert the calcium concentration in a prepared sample to the calcium content of the original biological specimen.

\section{Solutions with Low Calcium Concentration}

When the prepared sample is considered to have a low calcium concentration (below $10 \mathrm{mg} . / 100 \mathrm{ml}$.), $3 \mathrm{ml}$. of the supernatant is taken and $40 \%$ sodium hydroxide added until the $p \mathrm{H}$ is about 12 . Because of the small amount of buffer present, great care is necessary in the addition of alkali. A final solution that is not alkaline enough will not give an end-point ; a final solution that is too alkaline gives a difficult end-point. Buffer $(3 \mathrm{ml}$.) and a small knife point of indicator are then added. The blank consists of $3 \mathrm{ml}$. water and $3 \mathrm{ml}$. glycine buffer.

$$
\begin{aligned}
& \frac{\text { Test-Blank }}{\text { Standard-Blank }} \\
& \text { prepared sample. }
\end{aligned}
$$

If the calcium concentration is very low, $5 \mathrm{ml}$. supernatant and $1 \mathrm{ml}$. buffer may be used.

\section{Micro Modification}

The method can be adapted when only small specimens are available for analysis. Preparation of the specimens follows similar lines to that described 
above. If ashing is necessary, about $500 \mathrm{mg}$. of tissue is weighed, ashed, and the ash dissolved in $0.1 \mathrm{ml}$. $\mathrm{N}-\mathrm{HCl}$ and $0.2 \mathrm{ml}$. water.

Phosphate Separation.-Of the prepared sample, $0.2 \mathrm{ml}$. is mixed with $0.1 \mathrm{ml}$. tungstate reagent and $0.2 \mathrm{ml}$. morpholine nitrate-nitric acid reagent and centrifuged. The supernatant is taken for titration.

\section{Titration}

Test.-For the test $0.1 \mathrm{ml}$. supernatant is pipetted into a small white crucible and the $p H$ adjusted to about 12 with $40 \% \mathrm{NaOH}$. Glycine buffer $(0.5 \mathrm{ml}$.) and a very small knife point of indicator (about 0.2 mg.) are added.

Standard.-For the standard, $0.1 \mathrm{ml}$. standard calcium solution $(10 \mathrm{mg} . / 100 \mathrm{ml}$.), $0.5 \mathrm{ml}$. buffer, and indicator are required.

Blank.-The blank requires $0.1 \mathrm{ml}$. distilled water, $0.5 \mathrm{ml}$. buffer, and indicator.

Test standard and blank are titrated with E.D.T.A. solution diluted 1 in 5 (an E.D.T.A. solution which is more dilute than this results in a poor end-point). (For serum, use $0.1 \mathrm{ml} .+0.5 \mathrm{ml}$. glycine buffer.)

\section{Calculation}

The calculation is as for the macro method above.

\section{RESULTS}

Each stage of the method has been examined.

\section{Ashing}

Table I shows that ashing is generally not necessary for the analysis of calcium in the biological specimens described here apart from soft tissues. Muscle (a typical soft tissue) was not accurately analysed by homogenization without ashing, and in such cases it is necessary to ash.

Table II shows that the ashing procedure adopted did not result in loss of calcium, and that, although adding acid before ashing, as described by Horner (1955), is unnecessary, dilute acid must be used to extract the ash.

\section{Phosphate Separation Compared with Oxalate Precipitation}

Serum calcium may be estimated directly without phosphate precipitation (Baron and Bell, 1957), but it is impossible to obtain a clear endpoint with urine and most other biological specimens by this method because of the interference caused by phosphates (Collier, 1955).

Morpholine nitrate and tungstate (Horner, 1955) have proved entirely satisfactory for removing phosphate before titration of calcium, resulting in an easily read end-point, no loss of calcium, or introduction of interfering ions.
TABLE I

EFFECT OF ASHING ON DETERMINATION OF CALCIUM IN BIOLOGICAL SPECIMENS

\begin{tabular}{|c|c|c|c|c|c|c|}
\hline \multirow{2}{*}{\multicolumn{4}{|c|}{ Biological Specimens }} & \multicolumn{3}{|c|}{ Calcium Found } \\
\hline & & & & \multirow{2}{*}{$\begin{array}{c}\text { Ashed } \\
115 \\
116\end{array}$} & \multirow{2}{*}{$\begin{array}{l}\text { Unashed } \\
\left.\begin{array}{l}116 \\
120\end{array}\right\}\end{array}$} & \multirow{3}{*}{$\frac{\text { Units }}{\text { mg. 'specimen }}$} \\
\hline \multicolumn{4}{|c|}{$\begin{array}{l}\text { Food I (chicken, bread, } \\
\text { milk, fruit, and vegetable) }\end{array}$} & & & \\
\hline $\begin{array}{r}\text { Food II } \\
\text { garine, a }\end{array}$ & $\begin{array}{l}\text { (beef, } \\
\text { and ce }\end{array}$ & $\begin{array}{l}\text { egg, } n \\
\text { reals) }\end{array}$ & nar- & $\begin{array}{l}440 \\
440 \\
425\end{array}$ & $\left.\begin{array}{l}422 \\
416 \\
432\end{array}\right\}$ & \\
\hline Faeces I & $\cdots$ & $\cdots$ & $\cdots$ & $\begin{array}{l}474 \\
482\end{array}$ & $\left.\begin{array}{l}489 \\
480\end{array}\right\}$ & mg. $/ 24$ hours \\
\hline II & $\cdots$ & $\cdots$ & $\cdots$ & $\begin{array}{l}519 \\
506\end{array}$ & $\left.\begin{array}{l}512 \\
519\end{array}\right\}$ & \\
\hline III & . & $\cdots$ & $\cdots$ & 867 & $\left.\begin{array}{l}861 \\
866\end{array}\right\}$ & \\
\hline Urine I & $\cdots$ & $\cdots$ & $\cdots$ & $5 \cdot 4$ & $\left.\begin{array}{l}5 \cdot 4 \\
5 \cdot 6\end{array}\right\}$ & $\mathrm{mg} . / 100 \mathrm{ml}$ \\
\hline II & $\cdots$ & $\cdots$ & $\cdots$ & $\begin{array}{l}6 \cdot 2 \\
6 \cdot 1 \\
\end{array}$ & $\left.\begin{array}{l}6 \cdot 2 \\
6 \cdot 2\end{array}\right\}$ & \\
\hline $\begin{array}{r}\text { Milk I } \\
\text { II } \\
\text { III }\end{array}$ & $\begin{array}{l}\cdots \\
\cdots \\
\cdots\end{array}$ & $\begin{array}{l}\cdots \\
\cdots \\
\cdots\end{array}$ & $\begin{array}{l}\cdots \\
\cdots \\
\cdots\end{array}$ & $\begin{array}{l}108 \\
115 \\
119\end{array}$ & $\begin{array}{l}111 \\
121 \\
123\end{array}$ & mg. $100 \mathrm{ml}$ \\
\hline $\begin{array}{l}\text { Whole too } \\
\text { Dentine } \\
\text { Enamel } \\
\end{array}$ & $\begin{array}{c}\text { th } \\
\ldots \\
\cdots \\
\end{array}$ & $\begin{array}{l}\cdots \\
\cdots \\
\cdots\end{array}$ & $\begin{array}{l}\cdots \\
\cdots \\
\cdots\end{array}$ & $\begin{array}{l}28 \cdot 2 \\
36 \cdot 4 \\
28 \cdot 2 \\
\end{array}$ & $\begin{array}{l}28 \cdot 2 \\
36 \cdot 2 \\
27 \cdot 9 \\
\end{array}$ & $\mathrm{mg} \cdot / 100 \mathrm{mg}$. \\
\hline Bone & . & . & $\cdots$ & $\begin{array}{l}250 \\
25.0\end{array}$ & $\left.\begin{array}{l}25.0 \\
24.9\end{array}\right\}$ & $\mathrm{mg} . / 100 \mathrm{mg}$. \\
\hline Muscle & $\cdots$ & $\cdots$ & $\cdots$ & $\begin{array}{l}5 \cdot 9 \\
5 \cdot 9 \\
5 \cdot 9\end{array}$ & $\left.\begin{array}{l}4 \cdot 5 \\
6 \cdot 5 \\
5 \cdot 6\end{array}\right\}$ & mg./100 g. \\
\hline
\end{tabular}

The biological specimens were prepared as described in the methods section. One portion of each of the prepared samples was ashed diluted to volume with water. A suitable aliquot of this solution, and another portion of the sample prepared as above, were treated with tungstate and morpholine nitrate-nitric acid reagent for phosphate precipitation. Calcium was estimated on the supernatants by E.D.T.A. titration.

TABLE II

INVESTIGATION OF DIFFERENT ASHING PROCEDURES

\begin{tabular}{|c|c|c|c|}
\hline & $\begin{array}{c}\text { Materials } \\
\text { Ashed }\end{array}$ & $\begin{array}{c}\text { Ash } \\
\text { Dissolved in }\end{array}$ & $\underset{(\mathrm{mg} . / 100 \mathrm{ml} .)}{\text { Calcium }}$ \\
\hline (a) & $\begin{array}{l}4 \mathrm{ml} \text {. serum } \\
4 \mathrm{ml} \text {. serum }+1 \mathrm{ml} \text {. conc. } \mathrm{HCl} \\
4 \mathrm{ml} \text {. serum }+1 \mathrm{ml} \text {. conc. } \\
\text { HNO }+1 \mathrm{ml} \text {. conc. } \mathrm{HCl} \\
4 \mathrm{ml} \text {. serum } \ldots\end{array}$ & $\begin{array}{l}4 \mathrm{ml} . \text { water } \\
0.2 \mathrm{ml} \text {. N-HCl} \\
3.8 \mathrm{ml} \text {. water } \\
0.2 \mathrm{ml} \text {. N-HCl } \\
3.8 \mathrm{ml} \text {. water }\end{array}$ & $\begin{array}{r}0.5 \\
0.4 \\
10 \cdot 0 \\
10 \cdot 0\end{array}$ \\
\hline
\end{tabular}

(b) Serum titrated directly without ashing

$10 \cdot 0$

(a) Specimens, each of $4 \mathrm{ml}$. of serum, were ashed overnight at $500^{\circ}$ and the ash taken up in the mixtures shown above. Calcium was estimated by the accepted oxalate procedure of Clark and Collip (1925).

(b) The serum was also titrated directly, without phosphate precipitation, by the method of Baron and Bell (1957).

Table III shows a comparison between the results of calcium analysis by this method (which takes one and a half hours to complete) and by standard oxalate precipitation methods. It can be seen that the compleximetric method seems to give results that are slightly lower, which has also been noted for serum analysis by Wilkinson (1957). 
TABLE III

COMPARISON BETWEEN RESULTS OBTAINED FOR CALCIUM ESTIMATION BY PRESENT METHOD AND A STANDARD OXALATE METHOD

\begin{tabular}{|c|c|c|c|c|}
\hline \multirow{2}{*}{\multicolumn{2}{|c|}{$\begin{array}{l}\text { Biological } \\
\text { Specimens }\end{array}$}} & \multicolumn{3}{|c|}{ Calcium Found } \\
\hline & & $\begin{array}{l}\text { Present } \\
\text { Method }\end{array}$ & $\begin{array}{l}\text { Oxalate } \\
\text { Method }\end{array}$ & Units \\
\hline Food I $\quad \ldots$ & . & $\begin{array}{l}116 \\
120\end{array}$ & $\left.\begin{array}{l}114 \\
112\end{array}\right\}$ & mg./specimen \\
\hline II & .. & $\begin{array}{l}422 \\
416 \\
432\end{array}$ & $\left.\begin{array}{l}440 \\
400 \\
428\end{array}\right\}$ & \\
\hline Faeces I & .. & $\begin{array}{l}512 \\
519 \\
519\end{array}$ & $\left.\begin{array}{l}530 \\
500\end{array}\right\}$ & mg. 24 hours \\
\hline II & .. & $\begin{array}{l}489 \\
480 \\
480\end{array}$ & $\left.\begin{array}{l}500 \\
515 \\
505\end{array}\right\}$ & \\
\hline $\begin{aligned} \text { Urine I } & \ldots \\
\mathbf{I I} & \cdots \\
\mathbf{I I I} & \cdots \\
\mathbf{I V} & \ldots \\
\mathbf{V} & \cdots \\
\mathbf{V I} & \ldots \\
\mathbf{V I I} & \cdots \\
\mathbf{V I I I} & \cdots \\
\mathbf{I X} & \cdots\end{aligned}$ & $\begin{array}{l}. \\
. \\
. \\
. \\
\ldots \\
. \\
.\end{array}$ & $\begin{array}{r}1 \cdot 8 \\
3 \cdot 3 \\
5.4 \\
5 \cdot 6 \\
10 \cdot 0 \\
17 \cdot 4 \\
17 \cdot 3 \\
31 \cdot 5 \\
10 \cdot 1^{*} \\
14 \cdot 6^{*} \\
25 \cdot 5^{*}\end{array}$ & $\left.\begin{array}{c}2.0 \\
3.6 \\
5.6 \\
5.6 \\
10.4 \\
19.0 \\
18.6 \\
30.8 \\
10.2 \\
14.6 \\
26\end{array}\right\}$ & mg. $100 \mathrm{ml}$. \\
\hline$\underset{\text { II }}{\text { Milk I }}$ & . & $\begin{array}{l}123 \\
132\end{array}$ & $\begin{array}{l}130 \\
140\end{array}$ & $\mathrm{mg} . / 100 \mathrm{ml}$. \\
\hline $\begin{array}{l}\text { Whole tooth } \\
\text { Enamel } \\
\text { Dentine .. }\end{array}$ & $\begin{array}{l}\cdots \\
\cdots \\
\cdots\end{array}$ & $\begin{array}{l}28 \cdot 2 \\
36 \cdot 2 \\
27 \cdot 9\end{array}$ & $\begin{array}{l}28 \cdot 6 \\
36 \cdot 4 \\
29 \cdot 0\end{array}$ & mg. $/ 100 \mathrm{mg}$. \\
\hline Bone & .. & $\begin{array}{l}25 \cdot 0 \\
24.9\end{array}$ & $24 \cdot 9\}$ & mg. $/ 100 \mathrm{mg}$. \\
\hline Muscle .. & . & $\begin{array}{l}5.9 \\
5.9\end{array}$ & $\left.\begin{array}{l}5.9 \\
5.9\end{array}\right\}$ & $\mathrm{mg} . / 100 \mathrm{~g}$. \\
\hline
\end{tabular}

Present Method-Specimens of food, faeces, bone, teeth, and urine were prepared without ashing and muscle with ashing as described in the methods section, phosphate was precipitated with morpholine nitrate and tungstate, and calcium determined by E.D.T.A. titration. Micro-analysis of calcium, using $0.1 \mathrm{ml}$. cf the supernatant after phosphate precipitation as described in the methods section, was performed for those results marked by an asterisk.

Oxalate Method.-Specimens of food, faeces, muscle, and milk were ashed overnight at $500^{\circ}$, the ash dissolved in $\mathrm{N}-\mathrm{HCl}$ and diluted to volume with distilled water. Bone and teeth samples were prepared as described in the methods section. Urine was used without preparation. Calcium was estimated by oxalate-permanganate procedures by the methods of King and Wootton (1956) for urine and milk and of Hawk, Oser, and Summerson (1954) for food, faeces, muscle, bone, and teeth.

This method also appears more reliable, as duplicates show closer agreement than with the oxalate methods. It must be admitted, however, that the end-point of the permanganate-oxalate titration is sharper than that found with any of the metallo-indicators for calcium which have been tried.

Precipitation of phosphate using zirconium nitrate, a method which was modified from that described by Vogel (1954), was also tried, but did not prove satisfactory. While this work was in progress, another method of phosphate precipitation using metastannate was described (Ling, 1958). Although it was usually found satisfactory it did not always give reliable results because of the need to control accurately the factors involved, in particular the concentration of nitric acid. For this reason the morpholine method (as suggested by Wilkinson, 1957) seems more suited to routine work.

\section{Indicators}

In addition to calcein-thymolphthalein the other indicators investigated were "calcon," 1-(2hydroxy - 1 - naphthylazo)-2-naphthol-4-sulphonic acid (Hildebrand and Reilley, 1957), and "cal-red," 2 - hydroxy - 1 - (2-hydroxy-4-sulpho-1-naphthylazo)-3-naphthoic acid (Patton and Reeder, 1956). The end-point with these indicators was considered inferior to that of the recommended "calceinthymolphthalein," especially in the presence of serum protein. These other indicators can of course be used if the observer prefers their particular colour changes.

\section{Titration Volumes}

Provided that the $p \mathrm{H}$ was controlled, the use of a larger volume of supernatant in relation to the volume of buffer, when solutions of low calcium content are analysed, did not lead to loss of accuracy (Table IV).

\section{TABLE IV}

EFFECT OF VARYING AMOUNT OF SUPERNATANT ON RESULTS OF CALCIUM TITRATION

\begin{tabular}{c|c|c|c}
\hline Urine & $\begin{array}{c}\text { Supernatant } \\
\text { (ml.) }\end{array}$ & $\begin{array}{c}\text { Buffer } \\
\text { (ml.) }\end{array}$ & $\begin{array}{c}\text { Calcium } \\
\text { (mg./100 ml.) }\end{array}$ \\
\cline { 2 - 3 } I & $\left\{\begin{array}{l}5 \\
3\end{array}\right.$ & 1 & $4 \cdot 8$ \\
2 & 3 & 4.9 \\
II & $\left\{\begin{array}{l}5 \\
3\end{array}\right.$ & 1 & 4.7 \\
2 & 3 & 3.6 \\
\hline
\end{tabular}

Twelve millilitres of each of two different urines were treated with $6 \mathrm{ml}$ tungstate reagent and $12 \mathrm{ml}$. of morpholine nitrate-nitric acid reagent to precipitate phosphate, and varying amounts of the supernatant and buffer were taken for calcium estimation by E.D.T.A. titration.

\section{Recovery and Accuracy}

Recovery experiments were carried out using calcium oleate for faeces, calcium phosphate for food, calcium chloride for urine, and calcium lactate for milk. These compounds were used because they are the commonly occurring compounds of calcium in these biological specimens. Table $\mathrm{V}$ shows that satisfactory recovery of calcium was obtained in all cases.

In order to test the reproducibility of the method, calcium was estimated eight times on one urine. The coefficient of variation was $3.3 \%$, the mean calcium concentration being $17.4 \mathrm{mg}$./100 $\mathrm{ml}$. 
TABLE V

RECOVERY EXPERIMENTS

\begin{tabular}{|c|c|c|c|c|}
\hline $\begin{array}{l}\text { Biological } \\
\text { Specimen }\end{array}$ & $\begin{array}{l}\text { Calcium } \\
\text { Found }\end{array}$ & $\begin{array}{l}\text { Calcium } \\
\text { Calculated }\end{array}$ & Units & $\begin{array}{c}\text { Recovery } \\
(\%)\end{array}$ \\
\hline Urine & $\begin{array}{l}11 \cdot 63 \\
13 \cdot 6 \\
17 \cdot 3 \\
21 \cdot 98 \\
23 \cdot 7\end{array}$ & $\begin{array}{c}\text { (Original sample) } \\
13.6 \\
17.0 \\
21 \cdot 6 \\
24 \cdot 1\end{array}$ & $\mathrm{mg} . / 100 \mathrm{ml}$. & $\begin{array}{r}100 \\
105 \\
104 \\
97\end{array}$ \\
\hline Food & $\begin{array}{l}17 \cdot 6 \\
22 \cdot 4 \\
28 \cdot 9\end{array}$ & $\begin{array}{c}\text { (Original sample) } \\
\qquad \begin{array}{c}22.48 \\
28.89\end{array}\end{array}$ & $\underset{\text { preparation }}{\mathrm{mg} /}$ & $\begin{array}{r}98 \\
100\end{array}$ \\
\hline Milk & $\begin{array}{l}123 \\
175\end{array}$ & $\begin{array}{l}\text { (Original sample) } \\
173\end{array}$ & $\mathrm{mg} \cdot / 100 \mathrm{ml}$. & 104 \\
\hline Faeces .. & $\begin{array}{l}16 \cdot 2 \\
28 \cdot 5\end{array}$ & $\begin{array}{c}\text { (Original sample) } \\
29 \cdot 5\end{array}$ & $\mathrm{mg} . / 100 \mathrm{ml}$. & 92 \\
\hline
\end{tabular}

Calcium lactate was added to milk, calcium chloride to urine, calcium phosphate to food, and calcium oleate to faeces. The biological specimens were prepared as described in the methods section, phosphate precipitated with morpholine nitrate and tungstate section, phosphate precipitated with morpholine nitra
and the calcium estimated by titration with E.D.T.A.

TABLE VI

EFFECT OF BARIUM AND MAGNESIUM SALTS ON ESTIMATION OF CALC

\begin{tabular}{|c|c|c|}
\hline $\begin{array}{l}\text { Final concentration of added } \\
\text { magnesium }(\mathrm{mg} . / 100 \mathrm{ml} .)\end{array}$ & 0 & 25 \\
\hline $\begin{array}{cl}\text { Calcium: } & \\
\text { mg. } / 100 \mathrm{ml} \text {. bone solution } \\
,, & \text { urine }\end{array}$ & $\begin{array}{r}24 \cdot 9 \\
3 \cdot 7\end{array}$ & $\begin{array}{r}24 \cdot 9 \\
3 \cdot 7\end{array}$ \\
\hline $\begin{array}{r}\text { Final concentration of } \\
\text { barium (g. } / 24 \mathrm{hr} \text {. faeces) }\end{array}$ & 0 & 29.4 \\
\hline $\begin{array}{l}\text { Calcium: } \\
\text { mg. } / 24 \text { hr. faeces }\end{array}$ & $\begin{array}{l}519 \\
519\end{array}$ & $\begin{array}{l}575 \\
580\end{array}$ \\
\hline
\end{tabular}

Magnesium as magnesium sulphate was added to bone solution and urine, and barium as barium sulphate to faeces, to give the final concentrations shown below. Phosphate and protein were precipitated with morpholine nitrate and tungstate and calcium estimated by E.D.T.A. titration.

\section{Interference}

The effects of magnesium and barium on the estimation of calcium by this method were tested (Table VI).

Magnesium sulphate was added to a solution of bone (prepared as described above), and to urine, to give in each case an increase in the magnesium concentration of about $25 \mathrm{mg}$. $/ 100 \mathrm{ml}$. Although the added magnesium concentration of the urine was seven times as great as the calcium concentration no effect was observed on the calcium estimated. Similarly, added magnesium did not alter the estimated calcium concentration in bone.

A large quantity of barium, as barium sulphate (1 g. to $50 \mathrm{ml}$. prepared faeces sample), had only a small effect on the estimated calcium. This concentration of barium might be found in the faeces of a patient after barium sulphate had been given for radiological examination.

\section{DISCUSSION}

It was necessary to devise a method of calcium estimation that was applicable to any sort of biological specimen, whether of high or low calcium concentration. The method had to be accurate and speedy, and capable of performance in any biochemical laboratory without specialized equipment.

The classical method of calcium estimation in biological samples involved ashing of the sample and precipitation of the calcium as oxalate before eventual permanganate titration or gravimetric analysis (Hawk et al., 1954). This method has many disadvantages. The calcium oxalate precipitate is difficult to handle when only small quantities of calcium are present, and the washing procedure is tedious if sufficient care is taken neither to leave excess oxalate nor to lose any precipitate. It is also advisable to allow eight hours to ensure complete precipitation.

In recent years methods for the final estimation of calcium in the prepared sample have been introduced utilizing either flame photometry or titration with E.D.T.A.

Flame photometry of calcium is difficult because of the weakness of the calcium bands in relation to the sodium line, and because of phosphate interference. If an ordinary commercial flame photometer is used, calcium can only be estimated after separation as oxalate (Butterworth, 1957), which is of little advantage even though washing the precipitate is unnecessary. Otherwise it is necessary to use a specially designed instrument (MacIntyre, 1957) or an expensive commercial instrument (Jackson and Irwin, 1957) which are not available in small laboratories. With these methods biological specimens have first to be prepared to eliminate the interference caused by phosphate and protein.

Titrimetric estimation of calcium with E.D.T.A. using the earlier indicators such as ammonium purpurate (Horner, 1955; Wilkinson, 1957 ; Dunstone, 1957) is not completely satisfactory as a routine method because the indefinite end-point cannot be determined visually. This makes it necessary to perform the titration in an absorptiometer.

The newer indicator, "calcein" (Diehl and Ellingboe, 1956), gives a sharp end-point for calcium at a $p H$ of about 12.5 and magnesium is not estimated. This end-point is detectable by the naked eye without any difficulty when the fluorescence of the "calcein " is masked by thymolphthalein (Tucker, 1957). The calcium may first be separated by oxalate precipitation with its known 
disadvantages: this was done by Gilbert and McGann (1958), using "cal-red" as the indicator, for the estimation of calcium in muscle. Yarbro and Golby (1958) used "calcon" as the indicator for the estimation of calcium in urine; they titrated with E.G.T.A. (ethylene glycol bis ( $\beta$-aminoethyl ether) $\mathbf{N}_{1} \mathbf{N}^{\prime}$, tetra-acetic acid), removed protein if present, and claim that phosphate separation is then unnecessary. We consider that a method of calcium estimation which is generally applicable to biological materials must involve separation of calcium from phosphate, and any method which requires precipitation of calcium as oxalate is not as satisfactory in routine use as one which involves precipitation of the phosphate.

\section{SUMMARY}

A method is described for titrimetric estimation of calcium in biologica: specimens which does not involve oxalate precipitation. It is simple and takes about one and a half hours.

Preliminary ashing is only required for tissues of low calcium concentration.

Interference by phosphate is removed by precipitation with morpholine nitrate and tungstate. The calcium in the phosphate-free supernatant is titrated with E.D.T.A. (sodium edetate) at $p \mathrm{H} \quad 12.6$ using a calcein-thymolphthalein indicator. Magnesium causes no interference.

Recoveries of calcium added to food, faeces, milk, and urine were satisfactory.

We thank Mr. W. G. Armstrong (Eastman Dental Hospital) for supplying the teeth, and the Dietetic and Catering Departments (Royal Free Hospital) for the food.

\section{ADDENDUM}

Since submitting this paper, we have tested acid alizarin black (Belcher, 1958), kindly supplied by Dr. Belcher and obtainable commercially. This indicator is stable for a few days in $0.5 \%$ aqueous solution; one drop is used for the titration. There is a sharp colour change from purple to a stable turquoise blue at the end-point, and this indicator is recommended. However, if removal of supernatant after phosphate separation with morpholinetungstate is not done carefully, a faint blue colour may occur after adding alkali, which makes this blue end-point less easy to see.

\section{REFERENCES}

Barney, J. D., and Sulkowitch, H. W. (1937). J. Urol. (Baltimore), $37,746$.

Baron, D. N., and Bell, J. L. (1957). Clin. Chim. Acta, $2,327$.

Belcher, R. (1953). Talanta, 1, 238.

Butterworth, E. C. (1957). J. clin. Path., 10, 379.

Clark, E. P., and Collip, J. B. (1925). J. biol. Chem., 63, 461.

Collier, R. E. (1955). Chem. and Ind. (Rev.), 74, p. 587.

Diehl, H., and Ellingboe, J. L. (1956). Analyt. Chem., 28, 882.

Dunstone, J. R. (1957). Med. J. Aust., 2, 571.

Follis, R. H., Jr. (1952). J. biol. Chem., 194, 223.

Gilbert, D. L., and McGann, J. (1958). Proc. Soc. exp. Biol. (N.Y.), 97, 791.

Hawk, P. B., Oser, B. L., and Summerson, W. H. (1954). Practical Physiological Chemistry, 13th ed., p. 962. Churchill, London.

Hildebrand, G. P., and Reilley, C. N. (1957). Analyt. Chem., $29,258$. Horner, W. H. (1955). J. Lab. clin. Med., 45, 951.

Jackson, W. P. U., and Irwin, L. (1957). J. clin. Path., 10, 383

King, E. J., and Wootton, I. D. P. (1956). Micro-analysis in Medical Biochemistry, 3rd ed., p. 166. Churchill, London.

Ling, E. R. (1958). Analyst, 83, 179.

MacIntyre, I. (1957). Biochem. J., 67, 164.

Patton, J., and Reeder, W. (1956). Analyt. Chem., 28, 1026.

Tucker, B. M. (1957). Analyst, 82, 284.

Vogel, A. I. (1954). A Text-book of Macro and Semimicro Qualitative Inorganic Analysis, 4th ed., p. 487. Longmans Green, London. Wilkinson, R. H. (1957). J. clin. Path., 10, 126.

Yarbro, C. L., and Golby, R. L. (1958). Anal. Chem., 30, 504. 
explanation. It is hardly surprising that the trouble arose after the introduction of penicillinstreptomycin pessaries, because any substance that removes the normal bacterial flora leaves the treated area ripe for colonization by antibioticresistant organisms, including staphylococci.

\section{Summary}

An account is given of staphylococcal cystitis due to cross-infection. It is suggested that the infection was due to catheterization and was favoured by the use of antibiotic pessaries. The organisms probably came from the blankets and dust. Measures taken to reduce this source of infection were successful in controlling the outbreak.

I wish to thank Mr. J. S. Hovell and Mr. K. Girgis for their help and co-operation which made this investigation possible, and Miss Yarker, the ward sister, for her valuable assistance.

\section{REFERENCES}

Blowers, R., and Wallace, K. R. (1955). Lancet, 1, 1250.

Dutton, A. A. C., and Ralston, M. (1957). Ibid., 1, 115.

Kirby, W. M. M., Corpron, D. O., and Tanner, D. C. (1956). J. Amer. med. Ass., 162, 1.

Ørskov, I. (1952). Acta path. microbiol. scand., Suppl. 93, p. 259. (1954). Ibid., 35, 194.

\section{Correction}

In the paper "Compleximetric Determination of Calcium in Pathological and Physiological Specimens," by D. N. Baron and Joyce L. Bell (J. clin. Path., 1959, 12, 143), there is an error in the last paragraph of column 2 on page 143. The second sentence should read:

"Then $1 \mathrm{ml}$. urine is added to the first tube and $0.2 \mathrm{ml}$. to the second tube." 